\title{
Bottleneck in secretion of a-amylase in Bacillus subtilis
}

\author{
Shaomin Yan and Guang Wu* (D)
}

\begin{abstract}
Amylase plays an important role in biotechnology industries, and Gram-positive bacterium Bacillus subtilis is a major host to produce heterogeneous a-amylases. However, the secretion stress limits the high yield of a-amylase in $B$. subtilis although huge efforts have been made to address this secretion bottleneck. In this question-oriented review, every effort is made to answer the following questions, which look simple but are long-standing, through reviewing of literature: (1) Does a-amylase need a specific and dedicated chaperone? (2) What signal sequence does CsaA recognize? (3) Does CsaA require ATP for its operation? (4) Does an unfolded a-amylase is less soluble than a folded one? (5) Does a-amylase aggregate before transporting through Sec secretion system? (6) Is a-amylase sufficient stable to prevent itself from misfolding? (7) Does a-amylase need more disulfide bonds to be stabilized? (8) Which secretion system does PrsA pass through? (9) Is PrsA ATP-dependent? (10) Is PrsA reused after folding of a-amylase? (11) What is the fate of PrsA? (12) Is trigger factor (TF) ATP-dependent? The literature review suggests that not only the most of those questions are still open to answers but also it is necessary to calculate ATP budget in order to better understand how $B$. subtilis uses its energy for production and secretion.
\end{abstract}

Keywords: a-Amylase, B. subtilis, Chaperone, Production, Secretion

\section{Background}

Amylase, especially $\alpha$-amylase, is an important biological product with its wide applications in clinical practice $[1$, $2]$ and in industry [3, 4]. For this reason, bacteria are considered as an important cell factory to produce $\alpha$-amylase [5], especially a Gram-positive bacterium, Bacillus subtilis, because of its high yield of designed proteins [6,7], its free of endotoxins, and its simplicity in terms of a few hundreds of proteins making up a viable cell [8].

Although $B$. subtilis frequently serves as a model bacterium to enrich our knowledge on how different mechanisms work in bacteria [9], it does produce desired products economically and profitably, such as riboflavin [10-12], branched-chain amino acids [13], amylase [14], etc.

To increase the production of $\alpha$-amylase in B. subtilis, heterologous $\alpha$-amylases are introduced into B. subtilis, for instances, AmyL comes from B. licheniformis [15],

*Correspondence: hongguanglishibahao@yahoo.com

National Engineering Research Center for Non-food Biorefinery, Guangxi

Academy of Sciences, 98 Daling Road, Nanning 530007, Guangxi, China
AmyM and AmyS come from Geobacillus stearothermophilus [14], and AmyQ comes from B. amyloliquefaciens [16]. These introductions are necessary because, for example, B. amyloliquefaciens demonstrates a strong ability in secretion but a weak ability in production, whereas B. subtilis does oppositely, and B. amyloliquefaciens has a bigger growth rate with larger cell density than B. licheniformis [17]. But most importantly, B. subtilis is used because its genetics is well known [8] and there are many molecular tools to manipulate it $[8,18]$.

However, incompatibility between $\alpha$-amylase production and secretion is observed, and becomes the bottleneck in industrial production of $\alpha$-amylase, and is termed as the secretion stress [19]. Primarily the secretion stress goes through three steps, the overproduction and hyper-secretion of $\alpha$-amylases upregulate the secretion stress-responsive CssR-CssS regulatory system, then the CssR-CssS regulatory system upregulates $\mathrm{HtrA}$ and $\mathrm{HtrB}$ proteases $[14,19]$, and the proteases in turn degrade the secreted $\alpha$-amylases via the Sec secretion system. Their consequence is the loss of secreted $\alpha$-amylases. Hence, this bottleneck is mainly related to three systems (i) Sec 
secretion system, (ii) CssR-CssS regulatory system, and (iii) HtrA and HtrB system.

So far, numerous investigations have been carried out to address this bottleneck from different angles not only because these three systems themselves are composed of many components but also because these components are involved in many processes. These studies are performed at signal peptide level [20-22], at chaperone level [23-25], at protease level [26, 27], at folding level [28, 29], at promoter level [30-33], at DNA level [34], at transcriptome level [35, 36], at secretion system level [37], at stress response level [38, 39], at fermentation level [14], etc.

Collectively, the bottleneck has been studied in great details although unsolved problems are still there. For example, it has been reported that overexpression of secretion systems is time-consuming and not efficient in $B$. subtilis for $\alpha$-amylase production [15, 40]. Since the secretion stress looks like a chain reaction, that is, it first begins from Sec secretion system and ends up to HtrA and HtrB system. Sec secretion system draws a considerable attention [15] although the other secretion systems also appear on radar screen [37]. Probably, the most efficient and effective way to deal with the bottleneck should start with Sec secretion system since it performs well before the initiation of secretion stress. Moreover, $\alpha$-amylase is a secretory protein whose secretion process should tightly relate to each step of secretion in $B$. subtilis.

At this point, questions come out and require answers and further studies in light of $\alpha$-amylase secretion and production. In particular, the following long-standing questions have yet to be answered. (1) Does $\alpha$-amylase need a specific and dedicated chaperone? (2) What signal sequence does CsaA recognize? (3) Does CsaA require ATP for its operation? (4) Does an unfolded $\alpha$-amylase is less soluble than a folded one? (5) Does $\alpha$-amylase aggregate before transporting through Sec secretion system? (6) Is $\alpha$-amylase sufficient stable to prevent itself from misfolding? (7) Does $\alpha$-amylase need more disulfide bonds to be stabilized? (8) Which secretion system does PrsA pass through? (9) Is PrsA ATP-dependent? (10) Is PrsA reused after folding of $\alpha$-amylase? (11) What is the fate of PrsA? (12) Is trigger factor (TF) ATP-dependent? Thus, attempting to answer these questions through reviewing of literature is designed as the aim of this question-oriented review.

\section{Chaperone for a-amylase}

Gram-positive bacteria have a single cytoplasmic membrane and it is generally considered that they have six secretion systems: (i) the Sec secretion system for unfolded proteins [29, 41, 42], (ii) the twin-arginine translocation (Tat) secretion system for folded proteins
[43], (iii) the fimbrillin-protein exporter (FPE) for the proteins that form pilin-like structures [44], (iv) the flagella export apparatus (FEA) for the proteins that form the flagella hook, filament, and cap [45], (v) the timed holin pore for the fully folded endolysin that degrades the cell wall during the phage lytic cycle [46], and (vi) the ESAT-6/WXG100 secretion system (WSS) for the proteins that contain a WXG motif [47] including virulence factors in some pathogenic bacteria [48, 49].

Main commercial production of amylases is produced by Bacillus species including $B$. acerans, $B$. acidocaldarius, B. amyloliquefaciens, B. licheniformis, B. stearothermophilus, B. subtilis and Bifidobacterium bifidum [50]. For protein secretion, B. subtilis uses four pathways: SecSRP (signal recognition particle) pathway, Tat pathway, $A B C$ transporters and pseudopilin export pathway [51], based on the studies on signal peptides [52]. The majority of produced $\alpha$-amylases is secreted through Sec-SRP pathway, and the rest passes through Tat pathway and ABC (ATP-binding cassette) transporters.

The SRP, which is the ribosome-associated RNA-protein complex and defined as the only secretion-specific chaperone Ffh protein [53], binds to hydrophobic signalanchor or signal sequence in nascent chains and targets them to the Sec translocon via interaction with its membrane receptor FtsY [54]. On the other hand, TF is also a cytosolic ribosome-bound protein [55].

In B. subtilis, CsaA could be a replacement of SecB to export preproteins, i.e. PrePhoB and ProOmpA [56, 57]. As a matter of fact, the existence of CsaA is not limited to $B$. subtilis because not only Gram-positive bacteria have SecB-like sequences [58] but also most archaea have homologues of CsaA [20,59]. Thus, the question is whether CsaA can work as a specific and dedicated chaperone to carry $\alpha$-amylase precursor to SecA in B. subtilis. The answer probably is not as shown by Müller et al. [56] that the export of most proteins remained unaffected when repressing the expression of the CsaA gene while only the export of two proteins, 19 and $36 \mathrm{kDa}$, was significantly reduced upon CsaA depletion, while $\alpha$-amylase is about $69 \mathrm{kDa}$ mass weight [29]. Furthermore, CsaA was found not to bind to the conserved SecB-binding domain in SecA [56]. So it would be hard to conclude that CsaA carries $\alpha$-amylase precursors to SecA with the same efficiency. Interestingly, Thermus thermophilus, a Gram-negative eubacterium, has both SecB and CsaA [60], therefore it would be great enlightening to analyze how SecB and CsaA work in this species. Moreover, it is unclear whether CsaA recognizes signal peptides because CsaA is indifferent to YvaY precursor and mature YvaY [61].

SecA usually binds to preproteins with mildly hydrophobic signal sequences [62], so it was suggested 
that SecA could serve as chaperone in B. subtilis [63] because the level of cytosolic SecA in B. subtilis is relatively high [64]. Interestingly, it was found that sodium azide, an ATPase inhibitor on SecA, had no influence on $\alpha$-amylase secretion in $B$. amyloliquefaciens as early as in 1975 [65]. This suggests that either $\alpha$-amylase does not go through Sec secretion system in B. amyloliquefaciens because sodium azide inhibits the secretion of cytotoxin in B. cereus [66], or SecA does not serve as chaperone to bind $\alpha$-amylase.

Preprotein translocation is a process requiring energy provided by the peripheral membrane-associated ATPase SecA, whose cycling repeats from ATP binding to hydrolysis to initiate the stage of further translocation process [20]. Thus, we may wonder whether the overproduction of $\alpha$-amylase exhausts the ATP source in B. subtilis whose ATP-dependent SecA, DnaK and GroEL cannot work well for secretion. Also, it is not clear whether TF is dependent upon ATP? As the major function of TF, DnaK and GroEL is to fold proteins, it is likely that they do not work for Sec secretion system because Sec secretion system requires unfolded proteins with signal peptides [20,67]. As a whole, it is unlikely that $\alpha$-amylase has a specific and dedicated chaperone.

\section{Binding of signal peptide}

In fact, $\alpha$-amylase secretion is not limited to Sec secretion system. For example, Corynebacterium glutamicum $\mathrm{R}$ is also a Gram-positive bacterium producing heterologous proteins such as amylase [68], nuclease, protease [69], transglutaminase [70], epidermal growth factor [71], protein glutaminase [72], etc. A screening of secretory proteins on its genome shows that 108 of 405 candidate signal peptides are able to heterologously secrete an active-form $\alpha$-amylase derived from G. stearothermophilus, including 98 Sec-type and 10 Tat-type peptides [73]. For these 98 Sec-type $\alpha$-amylases in C. glutamicum $R$, their average length of signal peptides is 36.6 residues and longer than those of 166 Sec-type proteins in B. subtilis [20], which have 28 residues ranging from 19 to 44 residues. In $B$. subtilis, about 300 endogenous proteins including $\alpha$-amylase are secreted through Sec system [74], and AmyE has 36 residues, MFAKRFKTSLLPLFAGFLLLFHLVLAGPAAASAETA [20]. Although the average length of signal peptides is about 35 residues for 10 Tat-type $\alpha$-amylases in C. glutamicum R, AmyX in $B$. subtilis has 30 residues, MVSIRRSFEAYVDDMNIITVLIPAEQKEIM [20]. Therefore, these findings suggest that some $\alpha$-amylases, like AmyX, are in the folded form before reaching secretion system because Sec secrets unfolded protein with signal peptide $[20,67]$ whereas Tat secrets folded protein with signal peptide $[75,76]$. Of the identified extracellular proteins, about 80 proteins pass through the Sec secretion system [77], fewer proteins such as PhoD and YwbN pass through Tat system [78], and the rest proteins may pass through $\mathrm{ABC}$ transporters [52].

PrsA, which is a post-translocation chaperone [79, 80], helps the folding of proteins secreted from Sec secretion system $[28,29]$. It is vital $[23,81]$ and is closely related to $\alpha$-amylase production because its overproduction leads to the increase of $\alpha$-amylase production in B. stearothermophilus $[15,23,82,83]$, but also leads to the increase in the production of proteases [23]. Curiously, the competition between $\alpha$-amylase and PrsA has not been seen through secretion systems because PrsA as a lipoprotein should pass through either Sec or Tat secretion systems [20]. As a lipoprotein, PrsA needs signal peptide peptidase II to cut its signal peptides, and then moves across the membrane [20]. This is very intriguing because the signal peptides are generally applied to secretory proteins whereas chaperones are not subject to the classification of signal peptides.

The amount of proteins being synthesized in ribosomes would be proportional to occupied ribosomes, which could trigger the involvement of SRP and TF, however the results from the synthesis of $\alpha$-amylase from Pyrococcus furiosus-F30 did not show many occupations [17]. Therefore it is not very clear what type of signal peptides for these two ribosome-bound chaperones.

Currently, the signal peptide sequences are classified into four types according to the sequence that is recognized by signal peptide peptidase [20], and consequently each type of signal peptides controls a preprotein to direct a specific secretion system. So at this point, we could not answer the question of what signal peptide sequence CsaA can recognize? Along this line, it is highly likely that $\alpha$-amylase does not need a dedicated chaperone because our current knowledge so far suggests that each chaperone works for a specific secretion system whereas $\alpha$-amylase can go through different secretion systems. Of course, the non-classical secretion systems constantly get attention, which do not need the signal peptides [37].

\section{Folding of a-amylase}

It is no doubt that the rate of protein folding is a determinant factor for production of $\alpha$-amylase [84], and so far the PrsA's role in folding of $\alpha$-amylase gets special attention. If we consider the possibility that a part of $\alpha$-amylases has already folded before reaching Tat system, then folding activity should extend into cytosolic compartment, where even Sec secretion system is influenced by the capacity of preventing premature folding, aggregation or degradation of preproteins [85], i.e., PrsA works on the trans side of the cytoplasmic membrane but 
is anchored, whereas the rest of chaperones works on the cis side of the cytoplasmic membrane but are free.

The involvement of PrsA in $\alpha$-amylase folding was known a longtime ago $[23,81,86]$. As PrsA is a $33-\mathrm{kDa}$ lipoprotein enriched with lysine, and its $\mathrm{N}$-terminal cysteine attaches cytoplasmic membrane with a thiollinked diacylglycerol [87, 88], the questions raised here are whether PrsA is reused after finishing the folding of an $\alpha$-amylase, and what is the fate of PrsA? Since the peptidoglycan has about 1300 disaccharides with about $20 \%$ of cross-linked peptide chains in B. subtilis [89], its permeability is limited to $25 \mathrm{kDa}$ globular proteins [90]. Naturally, $\alpha$-amylase is too large to go through the porous-structured cell wall with its $69 \mathrm{kDa}$ mass weight [29]. The numbers of PrsA are $2 \times 10^{4}$ per wild-type cell and $2 \times 10^{5}$ per enhanced secretion cell [79]. Now, it is not aware whether PrsA needs ATP, therefore it is hard to know how folded proteins are released from PrsA because the binding of chaperone with the hydrophobic peptide segments of substrates is controlled by ATP binding and hydrolysis [91]. Likely, PrsA may have no need to reuse itself considering such a large number of PrsA in $B$. subtilis. As PrsA is anchored on cytoplasmic membrane, thus its distance to Sec secretion system should be significant otherwise there is no need to have so many PrsA.

Except for the role of PrsA in folding of $\alpha$-amylase, another question raised here is whether there are factors with antifolding activity, which could lead to the accumulation of unfolded and misfolded $\alpha$-amylase. This could be possible, because the cell wall with net negative charge influences protein folding [82], which is essentially not limited to $\alpha$-amylase but also to other heterogeneous proteins like levansucrase [92, 93]. Yet, calcium also plays a role in folding of $\alpha$-amylase [93]. Bacillus species can improve $\alpha$-amylase yield by inactivating the $d l t$ operon, which results in the absence of alanylation of teichoic acids [82]. Consequently, the negative charges increase at cell membrane leading to a higher affinity for cations, which favorite the stability of secreted proteins and catalyze their folding.

Nonetheless, either PrsA or calcium is relevant to trans side where the folding requires Skp, SurA, and PpiD, while TF, DnaK (HSP70) and GroEL (HSP60) to work in cis side. If we consider that most $\alpha$-amylases should be folded on trans side, not much attention may need to pay the folding process in cis side, although TF is the first chaperone to interact with most newly synthesized proteins co-translationally [94], and can delay the co-translational folding of large proteins [95-97].

DnaK also functions in stabilizing proteins for subsequent folding by GroEL. It is widely reported that a poorly folded protein forms inclusion bodies and is a very common phenomenon when protein folding systems are saturated. $\alpha$-Amylases enable to aggregate before transporting through Sec secretion system. Also, unfolded $\alpha$-amylase is less soluble than folded one because we find $\alpha$-amylase precursor (accession number H9BPX5) poorly soluble when using CamSol [98] to compute its solubility (Fig. 1).

Although PrsA serves as a post-translocation chaperone to help the folding of secreted proteins and similar chaperones, peptidyl-prolyl cis/trans isomerase, exist in Gram-negative bacteria [99, 100], it seems that B. subtilis lacks the enzymes involving in disulfide bonds because PrsA is the only chaperone outside the cytoplasmic membrane [79]. In addition, their native disulfide bondforming enzymes may have limited ability to form more disulfide bonds during the overproduction of heterologous proteins [101]. So a question raised here is whether $\alpha$-amylase needs more disulfide bonds to be stabilized? Indeed, if we pick up randomly several $\alpha$-amylases from $B$. subtilis, then we can find that not many cysteines in them. For example, each of A7DWA9, B8Y1H0, P00691, C0KWE6, G4F096 and G4NTU0 has one cysteine, each of G4PC62 and G4P8H4 has 2 cysteines, G4P133 has 3 cysteines, each of G4NTS1 and G4PA17 has 4 cysteines, G4P139 has 5 cysteines, and each of Q9R9H8, O06988 and G4P8I0 has 6 cysteines. As $\alpha$-amylase lacks cysteins, which could form disulfide bonds to stabilize itself as other secreted proteins [102], so this could be a reason why there are misfolded $\alpha$-amylase to be cleared by proteases. This is plausible because genes $\operatorname{tr} x A$ and $\operatorname{tr} x B$, which prevent preproteins from oxidizing and to form disulfide bonds [103], are not active during overproduction in B. subtilis. The effectiveness of acylated homoserine lactone (AHL) with unsaturated $C_{18}$ side chains was dependent on the number of double bonds in the acyl side chain [104]. In fact, not many secreted proteins in B. subtilis contain disulfide bonds [105]. Thus one may wonder whether the increase in thiol-disulfide oxidoreductase could be a way to stabilize $\alpha$-amylase to reduce misfolded $\alpha$-amylase. Indeed, it was showed that human interleukin-3 [106] and protease, both with a single disulfide bond, could be stable and efficiently secreted in B. subtilis [107]. On the contrary, it was showed in the past that human serum albumin and the human pancreatic $\alpha$-amylase with several disulfide bonds were poorly secreted in B. subtilis $[105,108]$. Clearly, more studies are needed in this regard.

\section{Conclusions}

In this question-oriented review, we attempted to find the answers to 12 questions that we conceived during our study through reviewing of literature. The answers to these questions are not only important to biotechnology industry but also meaningful to theoretical studies 


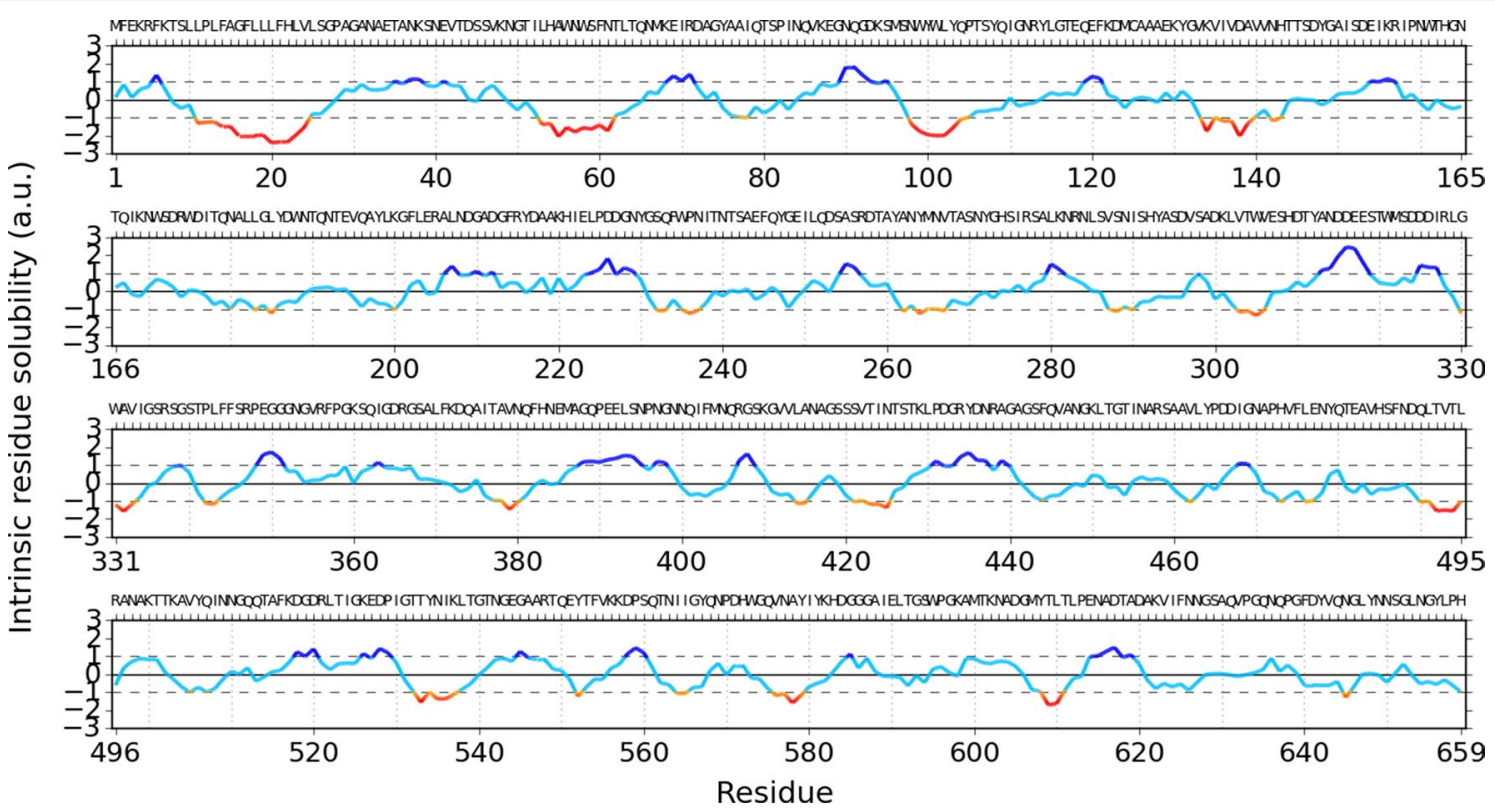

Fig. 1 Intrinsic solubility score obtained from CamSol for a-amylase precursor, where a residue is less soluble when its score is less than unity (not deep blue)

in microbiology. At this point, we can briefly summarize our answers as follows:

(1) Does $\alpha$-amylase need a specific and dedicated chaperone? No.

(2) What signal sequence does CsaA recognize? Unknown.

(3) Does CsaA require ATP for its operation? Unknown.

(4) Does an unfolded $\alpha$-amylase is less soluble than a folded one? Yes.

(5) Does $\alpha$-amylase aggregate before transporting through Sec secretion system? Yes.

(6) Is $\alpha$-amylase sufficient stable to prevent itself from misfolding? No.

(7) Does $\alpha$-amylase need more disulfide bonds to be stabilized? Yes.

(8) Which secretion system does PrsA pass through? Unknown.

(9) Is PrsA ATP-dependent? Unknown.

(10) Is PrsA reused after folding of $\alpha$-amylase? Unknown.

(11) What is the fate of PrsA? Unknown.

(12) Is TF ATP-dependent? Unknown.

So an important implication is that can we develop models to better understand the expenditure of ATP in $B$. subtilis and what is the best 3D structure for $\alpha$-amylase in order that it is stable and can be secreted smoothly without aggregation?
Hopefully our review can provide some clues to solve these pressing problems and advance our knowledge in this field. Indeed, many long-standing questions are eagerly waiting for their answers and inconsistent results remain to be addressed, and they are not obstacles for the development, but inspire the new endeavors. No doubt, the advance of modern technologies would bring the new prospective to overcome the bottleneck in the secretion of $\alpha$-amylase and enhance productivity of heterogeneous proteins in B. subtilis.

\section{Authors' contributions}

GW designed this study. Both SY and GW analyzed the data, prepared the figures, wrote and revised the manuscript. Both authors read and approved the final manuscript.

\section{Competing interests}

The authors declare that they have no competing interests.

This work was partially presented at the 14th China-Japan-Korea Joint Symposium on Enzyme Engineering on November 18, 2016, Nanning, China.

\section{Funding}

This study was partly supported by National Natural Science Foundation of China Nos. 31400079, 31460296, 21466007 and 31560315, and Special Funds for Building of Guangxi Talent Highland.

\section{Publisher's Note}

Springer Nature remains neutral with regard to jurisdictional claims in published maps and institutional affiliations.

Received: 27 January 2017 Accepted: 10 July 2017

Published online: 19 July 2017 


\section{References}

1. Voskuil MD, Mittal S, Sharples EJ, Vaidya A, Gilbert J, Friend PJ, Ploeg RJ. Improving monitoring after pancreas transplantation alone: fine-tuning of an old technique. Clin Transpl. 2014;28:1047-53.

2. Partelli S, Tamburrino D, Crippa S, Facci E, Zardini C, Falconi M. Evaluation of a predictive model for pancreatic fistula based on amylase value in drains after pancreatic resection. Am J Surg. 2014;208:634-9.

3. Dey TB, Banerjee R. Application of decolourized and partially purified polygalacturonase and a-amylase in apple juice clarification. Braz J Microbiol. 2014;45:97-104.

4. Jeon EJ, Jung JH, Seo DH, Jung DH, Holden JF, Park CS. Bioinformatic and biochemical analysis of a novel maltose-forming a-amylase of the GH57 family in the hyperthermophilic archaeon Thermococcus sp. CL1. Enzyme Microb Technol. 2014;60:9-15.

5. Ferrer-Miralles N, Villaverde A. Bacterial cell factories for recombinant protein production; expanding the catalogue. Microb Cell Fact. 2013;12:113.

6. Zweers JC, Barák I, Becher D, Driessen AJ, Hecker M, Kontinen VP, Saller MJ, Vavrová L, van Dijl JM. Towards the development of Bacillus subtilis as a cell factory for membrane proteins and protein complexes. Microb Cell Fact. 2008;7:10.

7. Liu L, Liu Y, Shin HD, Chen RR, Wang NS, Li J, Du G, Chen J. Developing Bacillus spp. as a cell factory for production of microbial enzymes and industrially important biochemicals in the context of systems and synthetic biology. Appl Microbiol Biotechnol. 2013;97:6113-27.

8. van Dijl JM, Hecker M. Bacillus subtilis: from soil bacterium to supersecreting cell factory. Microb Cell Fact. 2013;12:3.

9. Meeske AJ, Rodrigues CD, Brady J, Lim HC, Bernhardt TG, Rudner DZ. High-throughput genetic screens identify a large and diverse collection of new sporulation genes in Bacillus subtilis. PLoS Biol. 2016;14:e1002341.

10. Wang G, Bai L, Wang Z, Shi T, Chen T, Zhao X. Enhancement of riboflavin production by deregulating gluconeogenesis in Bacillus subtilis. World $J$ Microbiol Biotechnol. 2014;30:1893-900.

11. Duan YX, Chen T, Chen X, Zhao XM. Overexpression of glucose6-phosphate dehydrogenase enhances riboflavin production in Bacillus subtilis. Appl Microbiol Biotechnol. 2010;85:1907-14.

12. Wang Z, Chen T, Ma X, Shen Z, Zhao X. Enhancement of riboflavin production with Bacillus subtilis by expression and site-directed mutagenesis of zwf and gnd gene from Corynebacterium glutamicum. Bioresour Technol. 2011;102:3934-40.

13. Tojo S, Satomura T, Kumamoto K, Hirooka K, Fujita Y. Molecular mechanisms underlying the positive stringent response of the Bacillus subtilis ilv-leu operon, involved in the biosynthesis of branched-chain amino acids. J Bacteriol. 2008;190:6134-47.

14. Ploss TN, Reilman E, Monteferrante CG, Denham EL, Piersma S, Lingner A, Vehmaanperä J, Lorenz P, van Dijl JM. Homogeneity and heterogeneity in amylase production by Bacillus subtilis under different growth conditions. Microb Cell Fact. 2016;15:57.

15. Chen J, Fu G, Gai Y, Zheng P, Zhang D, Wen J. Combinatorial Sec pathway analysis for improved heterologous protein secretion in Bacillus subtilis: identification of bottlenecks by systematic gene overexpression. Microb Cell Fact. 2015;14:92.

16. Palva I. Molecular cloning of a-amylase gene from Bacillus amyloliquefaciens and its expression in Bacillus subtilis. Gene. 1982;19:81-7.

17. Wang P, Wang PL, Tian J, Yu XX, Chang MH, Chu XY, Wu NF. A new strategy to express the extracellular a-amylase from Pyrococcus furiosus in Bacillus amyloliquefaciens. Sci Rep. 2016;6:22229.

18. Harwood CR. Bacillus subtilis and its relatives: molecular biological and industrial workhorses. Trends Biotechnol. 1992:10:247-56.

19. Darmon E, Noone D, Masson A, Bron S, Kuipers OP, Devine KM, van Dij JM. A novel class of heat and secretion stress-responsive genes is controlled by the auto regulated CssRS two-component system of Bacillus subtilis. J Bacteriol. 2002;184:5661-71.

20. Tjalsma H, Bolhuis A, Jongbloed JD, Bron S, van Dijl JM. Signal peptidedependent protein transport in Bacillus subtilis: a genome-based survey of the secretome. Microbiol Mol Biol Rev. 2000;64:515-47.

21. Antelmann H, Tjalsma H, Voigt B, Ohlmeier S, Bron S, van Dijl JM, Hecker M. A proteomic view on genome-based signal peptide predictions. Genome Res. 2001;11:1484-502.
22. Brockmeier U, Caspers M, Freudl R, Jockwer A, Noll T, Eggert T. Systematic screening of all signal peptides from Bacillus subtilis: a powerful strategy in optimizing heterologous protein secretion in Gram-positive bacteria. J Mol Biol. 2006;362:393-402.

23. Kontinen VP, Sarvas M. The PrsA lipoprotein is essential for protein secretion in Bacillus subtilis and sets a limit for high-level secretion. Mol Microbiol. 1993:8:727-37.

24. Wu SC, Ye R, Wu XC, Ng SC, Wong SL. Enhanced secretory production of a single-chain antibody fragment from Bacillus subtilis by coproduction of molecular chaperones. J Bacteriol. 1998;180:2830-5.

25. Wu SC, Yeung JC, Duan Y, Ye R, Szarka SJ, Habibi HR, Wong SL. Functional production and characterization of a fibrin-specific single-chain antibody fragment from Bacillus subtilis: effects of molecular chaperones and a wall-bound protease on antibody fragment production. Appl Environ Microbiol. 2002;68:3261-9.

26. Wu XC, Lee W, Tran L, Wong SL. Engineering a Bacillus subtilis expression-secretion system with a strain deficient in six extracellular proteases. J Bacteriol. 1991;173:4952-8.

27. Feng J, Gu Y, Quan Y, Zhang W, Cao M, Gao W, Song C, Yang C, Wang S. Recruiting a new strategy to improve levan production in Bacillus amyloliquefaciens. Sci Rep. 2015;5:13814.

28. Lindholm A, Ellmen U, Tolonen-Martikainen M, Palva A. Heterologous protein secretion in Lactococcus lactis is enhanced by the Bacillus subtilis chaperone-like protein PrsA. Appl Microbiol Biotechnol. 2006;73:904-14.

29. Forster BM, Marquis $\mathrm{H}$. Protein transport across the cell wall of monoderm Gram-positive bacteria. Mol Microbiol. 2012;84:405-13.

30. Nicolas P, Mäder U, Dervyn E, Rochat T, Leduc A, Pigeonneau N, Bidnenko E, Marchadier E, Hoebeke M, Aymerich S, Becher D, Bisicchia P, Botella E, Delumeau O, Doherty G, Denham EL, Fogg MJ, Fromion V, Goelzer A, Hansen A, Härtig E, Harwood CR, Homuth G, Jarmer H, Jules M, Klipp E, Le Chat L, Lecointe F, Lewis P, Liebermeister W, March A, Mars RA, Nannapaneni P, Noone D, Pohl S, Rinn B, Rügheimer F, Sappa PK, Samson F, Schaffer M, Schwikowski B, Steil L, Stülke J, Wiegert T, Devine KM, Wilkinson AJ, van Dijl JM, Hecker M, Völker U, Bessières P, Noirot P. Condition-dependent transcriptome reveals high-level regulatory architecture in Bacillus subtilis. Science. 2012;335:1103-6.

31. Bongers RS, Veening JW, Van Wieringen M, Kuipers OP, Kleerebezem M. Development and characterization of a subtilin-regulated expression system in Bacillus subtilis: strict control of gene expression by addition of subtilin. Appl Environ Microbiol. 2005;71:8818-24.

32. Wang J, Ai X, Mei H, Fu Y, Chen B, Yu Z, He J. High-throughput identification of promoters and screening of highly active promoter-5'-UTR DNA region with different characteristics from Bacillus thuringiensis. PLoS ONE. 2013;8:e62960.

33. Song Y, Nikoloff JM, Fu G, Chen J, Li Q, Xie N, Zheng P, Sun J, Zhang D. Promoter screening from Bacillus subtilis in various conditions hunting for synthetic biology and industrial applications. PLOS ONE. 2016:11:e0158447.

34. Zhang G, Wang W, Deng A, Sun Z, Zhang Y, Liang Y, Che Y, Wen T. A mimicking-of-DNA-methylation-patterns pipeline for overcoming the restriction barrier of bacteria. PLOS Genet. 2012;8:e1002987.

35. Marciniak BC. Trip $H$, van-der Veek PJ, Kuipers OP. Comparative transcriptional analysis of Bacillus subtilis cells overproducing either secreted proteins, lipoproteins or membrane proteins. Microb Cell Fact. 2012;11:66.

36. Wilks JC, Kitko RD, Cleeton SH, Lee GE, Ugwu CS, Jones BD, BonDurant SS, Slonczewski JL. Acid and base stress and transcriptomic responses in Bacillus subtilis. Appl Environ Microbiol. 2009;75:981-90.

37. Chen J, Zhao L, Fu G, Zhou W, Sun Y, Zheng P, Sun J, Zhang D. A novel strategy for protein production using non-classical secretion pathway in Bacillus subtilis. Microb Cell Fact. 2016;15:69.

38. Zweers JC, Wiegert T, van Dijl JM. Stress-responsive systems set specific limits to the overproduction of membrane proteins in Bacillus subtilis. Appl Environ Microbiol. 2009;75:7356-64.

39. Lulko AT, Veening JW, Buist G, Smits WK, Blom EJ, Beekman AC, Bron S, Kuipers OP. Production and secretion stress caused by overexpression of heterologous alpha-amylase leads to inhibition of sporulation and a prolonged motile phase in Bacillus subtilis. Appl Environ Microbiol. 2007:73:5354-62. 
40. Chen J, Gai Y, Fu G, Zhou W, Zhang D, Wen J. Enhanced extracellular production of alpha-amylase in Bacillus subtilis by optimization of regulatory elements and over-expression of PrsA lipoprotein. Biotechnol Lett. 2015;37:899-906.

41. Desvaux M, Hébraud M, Talon R, Henderson IR. Secretion and subcelIular localizations of bacterial proteins: a semantic awareness issue. Trends Microbiol. 2009;17:139-45.

42. du Plessis DJ, Nouwen N, Driessen AJ. The Sec translocase. Biochim Biophys Acta. 1808;2011:851-65.

43. Robinson C, Matos CF, Beck D, Ren C, Lawrence J, Vasisht N, Mendel S. Transport and proofreading of proteins by the twin-arginine translocation (Tat) system in bacteria. Biochim Biophys Acta. 2011;1808:876-84.

44. Chen I, Dubnau D. DNA uptake during bacterial transformation. Nat Rev Microbiol. 2004;2:241-9.

45. Erhardt M, Namba K, Hughes KT. Bacterial nanomachines: the flagellum and type III injectisome. Cold Spring Harb Perspect Biol. 2010;2:a000299.

46. Wang IN, Smith DL, Young R. Holins: the protein clocks of bacteriophage infections. Annu Rev Microbiol. 2000;54:799-825

47. Sutcliffe IC. New insights into the distribution of WXG100 protein secretion systems. Antonie Van Leeuwenhoek. 2011;99:127-31.

48. Burts ML, Williams WA, Debord K, Missiakas DM. EsxA and EsxB are secreted by an ESAT-6-like system that is required for the pathogenesis of Staphylococcus aureus infections. Proc Natl Acad Sci USA. 2005;102:1169-74.

49. Abdallah AM, Gey van Pittius NC, Champion PA, Cox J, Luirink J, Vandenbroucke-Grauls CM, Appelmelk BJ, Bitter W. Type VII secretionmycobacteria show the way. Nat Rev Microbiol. 2007;5:883-91.

50. Rohban R, Amoozegar MA, Ventosa A. Screening and isolation of halophilic bacteria producing extracellular hydrolyses from Howz Soltan Lake, Iran. J Ind Microbiol Biotechnol. 2008;36:333-40.

51. Fu LL, Xu ZR, Li WF, Shuai JB, Lu P, Hu CX. Protein secretion pathways in Bacillus subtilis: implication for optimization of heterologous protein secretion. Biotechnol Adv. 2007;25:1-12.

52. Yamane $K$, Bunai $K$, Kakeshita H. Protein traffic for secretion and related machinery of Bacillus subtilis. Biosci Biotechnol Biochem. 2004;68:2007-23.

53. Honda K, Nakamura K, Nishiguchi M, Yamane K. Cloning and characterization of a Bacillus subtilis gene encoding a homolog of the 54-kilodalton subunit of mammalian signal recognition particle and Escherichia coli Ffh. J Bacteriol. 1993;175:4885-94.

54. Luirink J, Sinning I. SRP-mediated protein targeting: structure and function revisited. Biochim Biophys Acta. 2004;1694:17-35.

55. Lill R, Crooke E, Guthrie B, Wickner W. The, "trigger factor cycle" includes ribosomes, presecretory proteins and the plasma membrane. Cell. 1988:54:1013-8.

56. Müller JP, Ozegowski J, Vettermann S, Swaving J, Van Wely KH, Driessen AJ. Interaction of Bacillus subtilis CsaA with SecA and precursor proteins. Biochem J. 2000;348:367-73.

57. Müller JP, Bron S, Venema G, van Dijl JM. Chaperone-like activities of the CsaA protein of Bacillus subtilis. Microbiology. 2000;146:77-88.

58. Sala A, Calderon V, Bordes P, Genevaux P. TAC from Mycobacterium tuberculosis: a paradigm for stress-responsive toxin-antitoxin systems controlled by SecB-like chaperones. Cell Stress Chaperones. 2013;18:129-35.

59. van Wely KH, Swaving J, Freudl R, Driessen AJ. Translocation of proteins across the cell envelope of Gram-positive bacteria. FEMS Microbiol Rev. 2001;25:437-54

60. Shapova YA, Paetzel M. Crystallographic analysis of Bacillus subtilis CsaA. Acta Crystallogr Sect D. 2007;63:478-85.

61. Linde D, Volkmer-Engert R, Schreiber S, Müller JP. Interaction of the Bacillus subtilis chaperone CsaA with the secretory protein YvaY. FEMS Microbiol Lett. 2003;226:93-100.

62. Sala A, Bordes P, Genevaux P. Multitasking SecB chaperones in bacteria. Front Microbiol. 2014;5:666.

63. Herbort M, Klein M, Manting EH, Driessen AJM, Freudl RJ. Temporal expression of the Bacillus subtilis secA gene, encoding a central component of the preprotein translocase. J Bacteriol. 1999;181:493-500.

64. Swaving J, van Wely KH, Driessen AJM. Pre-protein translocation by a hybrid translocase composed of Escherichia coli and Bacillus subtilis subunits. J Bacteriol. 1999;181:7021-7.
65. Gould AR, May BK, Elliott WH. Release of extracellular enzymes from Bacillus amyloliquefaciens. J Bacteriol. 1975;122:34-40.

66. Diao L, Dong Q, Xu Z, Yang S, Zhou J, Freudl R. Functional implementation of the posttranslational SecB-SecA protein-targeting pathway in Bacillus subtilis. Appl Environ Microbiol. 2012;78:651-9.

67. Paetzel M, Karla A, Strynadka NC, Dalbey RE. Signal peptidases. Chem Rev. 2002;102:4549-80.

68. Smith MD, Flickinger JL, Lineberger DW, Schmidt B. Protoplast transformation in coryneform bacteria and introduction of an a-amylase gene from Bacillus amyloliquefaciens into Brevibacterium lactofermentum. Appl Environ Microbiol. 1986:51:634-9.

69. Liebl W, Sinskey AJ, Schleifer KH. Expression, secretion, and processing of staphylococcal nuclease by Corynebacterium glutamicum. J Bacteriol. 1992;174:1854-61.

70. Date M, Yokoyama K, Umezawa Y, Matsui H, Kikuchi Y. Production of native-type Streptoverticilliummobaraense transglutaminase in Corynebacterium glutamicum. Appl Environ Microbiol. 2003:69:3011-4.

71. Date M, Itaya H, Matsui H, Kikuchi Y. Secretion of human epidermal growth factor by Corynebacterium glutamicum. Lett Appl Microbiol. 2006;42:66-70.

72. Kikuchi Y, Itaya H, Date M, Matsui K, Wu LF. Production of Chryseobacterium proteolyticum protein-glutaminase using the twin-arginine translocation pathway in Corynebacterium glutamicum. Appl Microbiol Biotechnol. 2007;78:67-74.

73. Watanabe K, Tsuchida Y, Okibe N, Teramoto H, Suzuki N, Inui M, Yukawa $\mathrm{H}$. Scanning the Corynebacterium glutamicum R genome for highefficiency secretion signal sequences. Microbiology. 2009;155:741-50.

74. Tjalsma H, Antelmann H, Jongbloed JD, Braun PG, Darmon E, Dorenbos R, Dubois JY, Westers H, Zanen G, Quax WJ, Kuipers OP, Bron S, Hecker $M$, van Dijl JM. Proteomics of protein secretion by Bacillus subtilis: separating the "secrets" of the secretome. Microbiol Mol Biol Rev. 2004;68:207-33.

75. Berks BC, Sargent F, Palmer T. The Tat protein export pathway. Mol Microbiol. 2000;35:260-74.

76. Yen MR, Tseng YH, Nguyen EH, Wu LF. Saier MHJr. Sequence and phylogenetic analyses of the twin-arginine targeting (Tat) protein export system. Arch Microbiol. 2002:177:441-50.

77. Antelmann H, Van Dijl JM, Bron S, Hecker M. Proteomic survey through secretome of Bacillus subtilis. Methods Biochem Anal. 2006:49:179-208

78. Bendtsen JD, Nielsen H, Widdick D, Palmer T, Brunak S. Prediction of twin-arginine signal peptides. BMC Bioinform. 2005;6:167.

79. Vitikainen M, Pummi T, Airaksinen U, Wahlstrom E, Wu H, Sarvas M, Kontinen VP. Quantitation of the capacity of the secretion apparatus and requirement for PrsA in growth and secretion of alpha-amylase in Bacillus subtilis. J Bacteriol. 2001;183:1881-90.

80. Vitikainen M, Lappalainen I, Seppala R, Antelmann H, Boer H, Taira S Savilahti $H$, Hecker M, Vihinen M, Sarvas M, Kontinen VP. Structurefunction analysis of PrsA reveals roles for the parvulin-like and flanking $\mathrm{N}$ - and C-terminal domains in protein folding and secretion in Bacillus subtilis. J Biol Chem. 2004;279:19302-14.

81. Tjalsma H, Kontinen VP, Prágai Z, Wu H, Meima R, Venema G, Bron S, Sarvas M, van Dijl JM. The role of lipoprotein processing by signal peptidase II in the Gram-positive eubacterium Bacillus subtilis: signal peptidase II is required for the efficient secretion of a-amylase, a nonlipoprotein. J Biol Chem. 1999;274:1698-707.

82. Hyyrylainen HL, Vitikainen M, Thwaite J, Wu H, Sarvas M, Harwood CR, Kontinen VP, Stephenson K. D-Alanine substitution of teichoic acids as a modulator of protein folding and stability at the cytoplasmic membrane/cell wall interface of Bacillus subtilis. J Biol Chem. 2000;275:26696-703.

83. Vitikainen M, Hyyryläinen HL, Kivimäki A, Kontinen VP, Sarvas M. Secretion of heterologous proteins in Bacillus subtilis can be improved by engineering cell components affecting post-translocational protein folding and degradation. J Appl Microbiol. 2005:99:363-75.

84. Stephenson K, Carter NM, Harwood CR, Petit-Glatron MF, Chambert $R$. The influence of protein folding on late stages of the secretion of alpha-amylases from Bacillus subtilis. FEBS Lett. 1998;430:385-9.

85. Randall LL, Hardy SJ. SecB, one small chaperone in the complex milieu of the cell. Cell Mol Life Sci. 2002:59:1617-23. 
86. Bolhuis A, Tjalsma H, Smith HE, de Jong A, Meima R, Venema G, Bron S, van Dijl JM. Evaluation of bottlenecks in the late stages of protein secretion in Bacillus subtilis. Appl Environ Microbiol. 1999;65:2934-41.

87. Kontinen VP, Saris P, Sarvas M. A gene (prsA) of Bacillus subtilis involved in a novel, late stage of protein export. Mol Microbiol. 1991;5:1273-83.

88. Wahlström E, Vitikainen M, Kontinen VP, Sarvas M. The extracytoplasmic folding factor PrsA is required for protein secretion only in the presence of the cell wall in Bacillus subtilis. Microbiology. 2003;149:569-77.

89. Hayhurst EJ, Kailas L, Hobbs JK, Foster SJ. Cell wall peptidoglycan architecture in Bacillus subtilis. Proc Natl Acad Sci USA. 2008;105:14603-8.

90. Demchick P, Koch AL. The permeability of the wall fabric of Escherichia coli and Bacillus subtilis. J Bacteriol. 1996;178:768-73.

91. Mayer MP, Bukau B. Hsp70 chaperones: cellular functions and molecular mechanism. Cell Mol Life Sci. 2005;62:670-84.

92. Petit-Glatron MF, Grajcar L, Munz A, Chambert R. The contribution of the cell wall to a transmembrane calcium gradient could play a key role in Bacillus subtilis protein secretion. Mol Microbiol. 1993;9:1097-106.

93. Chambert R, Petit-Glatron MF. Anionic polymers of Bacillus subtilis cell wall modulate the folding rate of secreted proteins. FEMS Microbiol Lett. 1999:179:43-7.

94. Valent QA, Kendall DA, High S, Kusters R, Oudega B, Luirink J. Early events in preprotein recognition in E. coli: interaction of SRP and trigger factor with nascent polypeptides. EMBO J. 1995;14:5494-505.

95. Agashe VR, Guha S, Chang HC, Genevaux P, Hayer-Hartl M, Stemp M, Georgopoulos C, Hartl FU, Barral JM. Function of trigger factor and DnaK in multidomain protein folding: increase in yield at the expense of folding speed. Cell. 2004;117:199-209.

96. Hoffmann A, Becker AH, Zachmann-Brand B, Deuerling E, Bukau B, Kramer $\mathrm{G}$. Concerted action of the ribosome and the associated chaperone trigger factor confines nascent polypeptide folding. Mol Cell. 2012;48:63-74.

97. O'Brien EP, Christodoulou J, Vendruscolo M, Dobson CM. Trigger factor slows co-translational folding through kinetic trapping while sterically protecting the nascent chain from aberrant cytosolic interactions. J Am Chem Soc. 2012;134:10920-32.

98. Sormanni P, Aprile FA, Vendruscolo M. The CamSol method of rational design of protein mutants with enhanced solubility. J Mol Biol. 2015:427:478-90.
99. Dartigalongue C, Raina S. A new heat-shock gene, ppiD, encodes a peptidyl-prolyl isomerase required for folding of outer membrane proteins in Escherichia coli. EMBO J. 1998;17:3968-80.

100. Jakob RP, Koch JR, Burmann BM, Schmidpeter PA, Hunkeler M, Hiller $\mathrm{S}$, Schmid FX, Maier T. Dimeric structure of the bacterial extracellular foldase PrsA. J Biol Chem. 2015;290:3278-92.

101. Kouwen TR, van der Goot A, Dorenbos R, Winter T, Antelmann H, Plaisier MC, Quax WJ, van Dij JM, Dubois JY. Thiol-disulphideoxidoreductase modules in the low-GC Gram-positive bacteria. Mol Microbiol. 2007:64:984-99.

102. Sevier CS, Kaiser CA. Formation and transfer of disulphide bonds in living cells. Nat Rev Mol Cell Biol. 2002;3:836-47.

103. Nakano S, Küster-Schöck E, Grossman AD, Zuber P. Spx-dependent global transcriptional control is induced by thiol-specific oxidative stress in Bacillus subtilis. Proc Natl Acad Sci USA. 2003;100:13603-8.

104. Patzelt D, Wang H, Buchholz I, Rohde M, Gröbe L, Pradella S, Neumann A, Schulz S, Heyber S, Münch K, Münch R, Jahn D, Wagner-Döbler I, Tomasch J. You are what you talk: quorum sensing induces individual morphologies and cell division modes in Dinoroseobacter shibae. ISME J. 2013;7:2274-86.

105. Bolhuis A, Venema G, Quax WJ, Bron S, van Dijl RJM. Functional analysis of paralogous thiol-disulfide oxidoreductases in Bacillus subtilis. J Biol Chem. 1999;274:24531-8.

106. van Leen RW, Bakhuis JG, van Beckhoven FWC, Burger H, Dorssers J, Hommes RWJ, Lemson PJ, Noordam B, Persoon NLM, Wagemaker G. Production of human interleukin-3 using industrial micro-organisms. Bio/Technology. 1991;9:47-52.

107. Mansfeld J, Vriend G, Dijkstra BW, Veltmn OR, van den Burg B, Venema G, Ulbrich-Hofmann R, Eijsink VG. Extreme stabilization of a thermolysin-like protease by an engineered disulfide bond. J Biol Chem. 1997;272:11152-6.

108. Saunders CW, Schmidt BJ, Mallonee RL, Guyer MS. Secretion of human serum albumin from Bacillus subtilis. J Bacteriol. 1985;169:2917-25.

\section{Submit your next manuscript to BioMed Central and we will help you at every step:}

- We accept pre-submission inquiries

- Our selector tool helps you to find the most relevant journal

- We provide round the clock customer support

- Convenient online submission

- Thorough peer review

- Inclusion in PubMed and all major indexing services

- Maximum visibility for your research

Submit your manuscript at www.biomedcentral.com/submit
(O) BioMed Central 